\title{
A Research on Direct Participation of Staff in Glass Industry in India
}

\author{
D.Rajasekar, A.Krishna Sudheer
}

\begin{abstract}
In terms of Indian perspective, the anxiety over the direct participation of staff in industries is progressively becoming a common talk among the industries.For this issue many researcher have shown importance to find out the direct participation of staff in the glass industry with the relationship between knowledge and rewards system of the organisation.The purpose of this paper is to figure out the working atmosphere of glass industry specifically for employees one who showing the direct involvement in doing the work.Mean, Standard deviation and T-test applied in this paper to check the authenticity of data given by the respondents.The sample size of this study obtained from 60 respondents based on the population.For this study a simple random sampling has been used.
\end{abstract}

Key words- Organisation, Involvement, Employee satisfaction, Variables, goals.

\section{INTRODUCTION:}

The study of employee involvement among the employees of glass industry is important because there are various aspects of the work that are highly attractive and lead to satisfaction and aspect of the job also leads to dissatisfaction to an employee. There are many variables that have been hypothesized to be a result of job satisfaction or dissatisfaction.These include both those variables of job performance and those of deem. The degree of satisfaction of an employee are determined and analyse with the knowledge and the rewards paid to an employee by the industry based on the performance shown by an employee under the direct participation in the glass industry.

\section{REVIEW OF LITERATURE:}

MuhammedArifKhattak et al. (2013): Relationship between Employees Involvement and Organization Performance in Milieu of Pakistan. The research article measures the relationship among the direct participation of staff and Organisational performance in Pakistani organisations. A detailed study has been conducted on three main components of direct participation of staff namely, empowerment, team orientation and capacity development. It is proved that organisations who delegate authority to its employees perform better.

Winnie Kivuya (2015): Effects of Direct participation of staff in Strategic Management Implementation. The study was made to understand the effects of direct participation of staff in strategic management implementations. The study confirms that it is imperative for the managers to engage and involve employees to gain competitive edge for the

Revised Manuscript Received on April 12, 2019.

Dr.D.Rajasekar,Professor, AMET Business School, AMET Deemed to beUniversity, Chennai-603112.T.N, India.

Dr.A.KrishnaSudheer, Professor \& HOD, Dept. Of MBA, G.Pullaiah College of Engineering \& Technology, Kurnool-518452, Andhra Pradesh, India organisation. It highlights that in order to achieve the desired targets of the organisation, it is necessary that employees are permitted to involve.

\section{RESEARCH QUESTIONS}

The following are the research questions considered in the present study.

1. What are the significant factors influencing the direct participation of staff?

2. What are the individual and demographic characteristics that influence the direct participation of staff?

\section{RESEARCH OBJECTIVES}

* To studythe influence of demographic variables on the direct participation of staff.

* To determine the improvement of knowledge among the direct pariticipation of staff.

* To analyze the perception of the direct participation of staff towards the rewards system of the industry.

Hypotheses of the study

The following hypothesis were formulated in order to achieve the above objectives in the area of direct participation of staff

- There is no relationship between gender and direct participation of staff

- There is no relationship between age and direct participation of staff

Sources of Measurement Scales Used in the Questionnaire

\begin{tabular}{|l|l|l|}
\hline Variables for the Study & Sources & Scales \\
\hline \multirow{2}{*}{$\begin{array}{l}\text { Direct participation of } \\
\text { staff }\end{array}$} & Lawler & Knowledge, \\
& $(1996)$, & Reward, \\
& $\begin{array}{l}\text { Rose } \\
(2005) .\end{array}$ & Power, and \\
Information
\end{tabular}

Sampling Design:

Primary data: are collected from the employees through questionnaires. The conclusion has been drawn based on the analysis of the primary data.

Population Size :477

Sample size: The size of the sample means the number of sampling units selected from the population for investigation , 60 employees are selected from the direct participation of staff

Sampling technique: Simple random sampling

Published By:

Blue Eyes Intelligence Engineering 
Statistical tools

Mean,Standard deviation \& T-test

\section{RELIABILITY ANALYSIS FOR PILOT STUDY}

Based on reliability analysis and feedback from respondents, the final questionnaire was prepared.

\section{RELIABILITY ANALYSIS FOR PILOT STUDY\& RESULTS}

\begin{tabular}{|c|c|c|}
\hline $\begin{array}{l}\text { Scales used in } \\
\text { the study }\end{array}$ & $\begin{array}{c}\text { No. of } \\
\text { Items }\end{array}$ & Cronbach'sAlpha \\
\hline \hline $\begin{array}{l}\text { Direct } \\
\text { Participation of } \\
\text { Staff }\end{array}$ & 19 & 0.897 \\
\hline Knowledge & 4 & 0.696 \\
\hline Reward & 5 & 0.827 \\
\hline
\end{tabular}

Table: 1 Knowledge (scale) frequency distribution

\begin{tabular}{|l|c|c|c|c|c|c|c|}
\hline Scales & $\mathbf{1}$ & $\mathbf{2}$ & $\mathbf{3}$ & $\mathbf{4}$ & $\mathbf{5}$ & Mean & S.D. \\
\hline $\begin{array}{l}\text { 1. I receive sufficient training } \\
\text { to do my work. }\end{array}$ & 9 & 15 & 60 & 243 & 150 & 4.07 & 0.856 \\
\hline $\begin{array}{l}\text { 2. Shown myopportunity to } \\
\text { improve my competence in } \\
\text { my company. }\end{array}$ & 18 & 42 & 81 & 210 & 126 & 3.81 & 1.044 \\
\hline $\begin{array}{l}\text { 3. My supervisor motivate me } \\
\text { to obtain the developmental } \\
\text { experiences }\end{array}$ & 30 & 3 & 111 & 204 & 129 & 3.84 & 1.034 \\
\hline $\begin{array}{l}\text { 4. Feedback mechanism used } \\
\text { to know my performance }\end{array}$ & 30 & 27 & 54 & 219 & 147 & 3.90 & 0.700 \\
\hline
\end{tabular}

From the table 1, 31.4\% (150) of respondents are strongly agreed and $50.94 \%$ (243) were agreed with the statement "I receive sufficient training to do my work". Only $1.8 \%$ (9) was strongly disagreed with the mentioned statement. Thus, a mean of 4.07 was recorded for the statement. For the statement "Shown myopportunity to improve my competence in my company, $26.4 \%$ have strongly agreed and $44 \%$ have agreed, recording a mean value of 3.81. For the statement regarding the supervisor help and support, $27 \%$ have strongly agreed, $42.8 \%$ have agreed, $23.2 \%$ are neutral and $6.9 \%$ disagreed, recording a mean value of 3.84 . For the statement regarding the receiving of coaching and feedback, $30.8 \%$ have strongly agreed, $45.9 \%$ have agreed, $11.3 \%$ are neutral and $11.9 \%$ have disagreed, recording a mean score of 3.90. To determine the knowledge variable in the present study, the researcher has used four items (Statements) as listed in the above table.

Table 2: Rewards (scale) frequency distribution

\begin{tabular}{|c|c|c|c|c|c|c|c|}
\hline Scales (Rewards) & 1 & 2 & 3 & 4 & 5 & Mean & S.D. \\
\hline $\begin{array}{l}\text { 1. Satisfied with the work } \\
\text { when I do a good job with } \\
\text { the recognition }\end{array}$ & 30 & 39 & 90 & 219 & 99 & 3.67 & 1.087 \\
\hline $\begin{array}{l}\text { 2. Showing effort for this } \\
\text { company will pay reward }\end{array}$ & 60 & 36 & 99 & 192 & 90 & 3.45 & 1.239 \\
\hline $\begin{array}{l}\text { 3. If I perform well my salary } \\
\text { will be increase based on } \\
\text { my work performance. }\end{array}$ & 36 & 27 & 117 & 165 & 132 & 3.69 & 1.156 \\
\hline $\begin{array}{l}\text { 4. If I perform well my } \\
\text { performance appraisal } \\
\text { ratingswill be increased }\end{array}$ & 33 & 27 & 102 & 219 & 96 & 3.67 & 1.075 \\
\hline $\begin{array}{l}\text { 5. Based on the performance } \\
\text { can likely to be promoted }\end{array}$ & 54 & 27 & 87 & 189 & 120 & 3.62 & 1.239 \\
\hline
\end{tabular}

From the table 2, 20\% (99) of respondents are strongly agreed and 6\% (30) strongly disagreed with the statement "Satisfied with the work when I do a good job with the recognition". Thus, a mean of 3.67 was recorded for this statement. For the statement "Showing effort for this company will pay reward t", 90 respondents were strongly disagreed and 60 were strongly agreed with a mean of 3.45. For the statement "If I perform well my salary will be increase based on my work performance", strongly disagreed was 132 respondents and strongly agreed was 32 with a mean of 3.69. For the statement "Based on the performance can likely to be promoted",

Published By:

Blue Eyes Intelligence Engineering

\& Sciences Publication 
120 respondents were strongly agreed and 54 respondents were strongly disagreed with a mean of 3.62.Five item scales were considered in the study to examine the level of agreement of the respondents regarding their perception toward reward system in their organization.

Table 3 Summary table of scales used in the study

\begin{tabular}{|l|c|c|}
\hline Items & Mean & S.D. \\
\hline DIRECT PARTICIPATION OF STAFF & 3.90 & 0.700 \\
\hline Knowledge & 3.62 & 0.847 \\
\hline Reward & \multicolumn{2}{|c|}{} \\
\hline
\end{tabular}

Table 4 : Independent Sample T - Test: Between Gender and Direct Participation of Staff

\begin{tabular}{|c|c|c|c|c|c|c|}
\hline & & \multicolumn{2}{|c|}{$\begin{array}{c}\text { Levene's Test for } \\
\text { Equality of } \\
\text { Variances }\end{array}$} & \multicolumn{3}{|c|}{ t-test for Equality of Means } \\
\hline & & $\mathrm{F}$ & Sig. & $\mathrm{t}$ & $\mathrm{df}$ & $\begin{array}{c}\text { Sig. } \\
\text { (2-tailed) }\end{array}$ \\
\hline \multirow{2}{*}{ KNOWLEDGE } & $\begin{array}{l}\text { Equal variances } \\
\text { assumed }\end{array}$ & 10.421 & .001 & -7.539 & 475 & .000 \\
\hline & $\begin{array}{l}\text { Equal variances not } \\
\text { assumed }\end{array}$ & & & -9.509 & 189.460 & .000 \\
\hline \multirow{2}{*}{ REWARD } & $\begin{array}{l}\text { Equal variances } \\
\text { assumed }\end{array}$ & 8.532 & .004 & -7.069 & 475 & .000 \\
\hline & $\begin{array}{l}\text { Equal variances not } \\
\text { assumed }\end{array}$ & & & -8.556 & 175.444 & .000 \\
\hline \multirow{2}{*}{$\begin{array}{l}\text { EMPLOYEE } \\
\text { INVOLVEMENT }\end{array}$} & $\begin{array}{l}\text { Equal variances } \\
\text { assumed }\end{array}$ & 7.718 & .006 & -7.849 & 475 & .000 \\
\hline & $\begin{array}{l}\text { Equal variances not } \\
\text { assumed }\end{array}$ & & & -8.863 & 156.556 & .000 \\
\hline
\end{tabular}

\section{RESEARCH FINDINGS}

Based on the research question framed in the present study, the following findings were presented in detail across various companies selected:There is a significant difference between gender and direct participation, and found significant negative relationship between age and direct participation of staff.From the above can conclude that the glass industry ha shown a positive significance with direct participation of work.

\section{SUGGESTION AND CONCLUSION}

From the findings, it is clear that the staffmembers are satisfied with the glass industry.Even though the majority of staff satisfied but the remaining unsatisfied staff members also to be taken into consideration. All the above the staff members are happy in sharing the information , knowledge and more traditional approach with the industry in highlighting the positive outcome of pay.It is better to provide more training to the employees to develop their skill and should be well informed about their authority and responsibility.To conclude the employees should be motivate in the following of knowledge and reward to show or increase their participation in the industry. The study on direct participation with the employees was analysed through properly with the support of direct response from workers.For the purpose of the study the findings are listed out on the bases of proper analysis and suggestions are forwarded.

\section{REFERENCES}

1. MuhammedArifKhattak et al. (2013):International Journal of Academic Research in Business and Social Sciences, Vol. 1, No. 3 ISSN: 2222-6990

2. Winnie Kivuva (2015), ISSN 2320-5407 International Journal of Advanced Research Volume 3, Issue 8, 164-171. 